Joanna Nowak

ORCID 0000-0001-9706-9271

Instytut Slawistyki Polskiej Akademii Nauk

Zakład Badań Narodowościowych (Poznań, Polska)

joannanowak67@gmail.com

\title{
U początku kształtowania się na ziemiach polskich nowoczesnych nauk o człowieku i jego zróżnicowaniu „rasowym”
}

\begin{abstract}
Abstrakt
W artykule poddano analizie najwcześniejszy okres kształtowania się nowoczesnych nauk o człowieku, jego naturze, genezie oraz zróżnicowaniu fizycznym i kulturowym w refleksji polskiej. Ten kilkuetapowy proces rozpoczął się w momencie, gdy pod wpływem idei europejskiego oświecenia i rozwoju nauk przyrodniczych wzrosło zainteresowanie człowiekiem z nowej perspektywy, wolnej od religijnego determinizmu.

Pionierskie poszukiwania świeckiego ujęcia łączyły kreacjonizm i tradycję biblijną $z$ racjonalnym podejściem opartym na osiagnięciach z zakresu historii naturalnej, językoznawstwa, filozofii, historii i krytyki biblijnej.

W kolejnym etapie historia naturalna była już odrębną nauką z doprecyzowanym zakresem badań obejmującym, obok
\end{abstract}

\begin{tabular}{|c|c|c|c|c|c|}
\hline \multicolumn{2}{|c|}{$\begin{array}{l}\text { INFORMACJA } \\
\text { O PUBLIKACJI }\end{array}$} & Pistoriae & $\begin{array}{r}\text { e-ISSN 2543-702X } \\
\text { ISSN 2451-3202 }\end{array}$ & 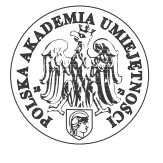 & $\begin{array}{l}\text { } \\
\text { BRYLANTOWY MODEL } \\
\text { OTWARTEGO DOSTĘPU }\end{array}$ \\
\hline \multicolumn{6}{|c|}{$\begin{array}{l}\text { CYTOWANIE } \\
\text { Nowak, Joanna 2021: U początku kształtowania się na ziemiach polskich nowoczesnych nauk o człowieku } \\
\text { i jego zróżnicowaniu „rasowym”. Studia Historiae Scientiarum 20, ss. 61-86. } \\
\text { DOI: } \underline{10.4467 / 2543702 X S H S .21 .004 .14035} \text {. }\end{array}$} \\
\hline \multicolumn{3}{|c|}{$\begin{array}{l}\text { OTRZYMANO: } 28.01 .2021 \\
\text { ZAAKCEPTOWANO: } 29.06 .2021 \\
\text { OPUBLIKOWANO ONLINE: } 13.09 .2021\end{array}$} & $\begin{array}{l}\text { POLITYKA } \\
\text { ARCHIWIZOWANIA } \\
\text { Green SHERPA/ } \\
\text { RoMEO Colour }\end{array}$ & (c) $\underset{\text { (i) }}{\text { LICENCJA }}$ & 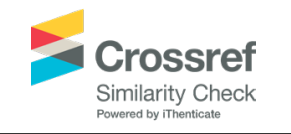 \\
\hline www & \multicolumn{5}{|c|}{ https://ojs.ejournals.eu/SHS/; http://pau.krakow.pl/Studia-Historiae-Scientiarum/archiwum } \\
\hline
\end{tabular}


mineralogii i botaniki, zoologię, w tym naukę o człowieku ujmowaną z perspektywy biologicznej. Pierwsze i nieliczne opinie o antropologii opisywały ją jako naukę dopiero wyodrębniająca się z historii naturalnej, badającą człowieka zarówno w aspekcie fizycznym, jak i moralnym.

Po 1831 r. nauki o człowieku kształtowały się w odmiennych realiach, gdy ośrodki naukowe, z przodującym w zakresie historii naturalnej Uniwersytetem Wileńskim, uległy likwidacji. Pod wpływem idei romantycznych propagowano pogląd o wyższości więzi umysłowych nad fizycznymi, zespolenia duchowego nad pokrewieństwem krwi, kultury nad biologia.

Akcent w rozważaniach o człowieku przeniesiono z dominującej pod koniec XVIII i na początku XIX w. historii naturalnej na kwestie związane $z$ umysłowością i kulturą. Rozwój wiedzy przyrodoznawczej, ale i humanistyki doprowadził do wyodrębnienia się nowych kierunków i obszarów badań, które wcześniej wchodziły w zakres historii naturalnej i historii. Oceniano, że badania nad człowiekiem wymagają łączenia rozmaitych metod, współpracy uczonych wielu nauk, ale bez utraty ich odrębności. Ten pionierski okres trwał do początku lat 60 . XIX w., gdy antropologia stała się na ziemiach polskich dyscypliną akademicką.

Słowa kluczowe: pojecie rasy, historia naturalna, antropologia, etnografia, etnologia

\title{
At the beginning of the development of modern human sciences and studies on "racial" diversity on the Polish lands
}

\begin{abstract}
The article analyses the earliest period of the shaping modern human sciences, studies on human nature, the origins of humans, and physical and cultural diversity of humans in Poland.

This process, including several separate stages, began under the influence of the ideas spread by the European Enlightenment and reflected the development of natural sciences that brought a deeper interest in humans, seen from a new perspective, free from religious determinism.
\end{abstract}


Pioneering searches for a secular approach combined creationism and biblical tradition with a rational attitude based on achievements in natural history, linguistics, philosophy, history, and biblical critique.

In the next stage, natural history constituted a distinct science with a precise scope of research that included, except mineralogy and botany, also zoology as well as human sciences perceived from a biological perspective. First definitions of anthropology described it as a science only emerging from natural history, with the aim to study both physical and moral aspects of humans.

After 1831, human sciences experienced a different situation in various Polish research centers that finally ceased to exist, including Vilnius University, the leader in research in natural history. Under the influence of Romantic ideas, a view was propagated that mental ties were superior to physical ones, spiritual ties to blood kinship, culture was more important than biology.

The emphasis in the study of humans was no longer on natural history, as in the late $18^{\text {th }}$ century and the early $19^{\text {th }}$ century, but on issues connected with mind and culture. The growth of both natural science and the humanities led to the establishment of new directions and areas of research that earlier were covered by natural history and history. Authors came to believe that study of humans requires a combination of various methods and cooperation of scholars representing numerous specialized sciences, however with their specific features preserved. This pioneering period lasted until the early $1860 \mathrm{~s}$ when anthropology became an academic discipline on the Polish lands (translated by Jacek Serwański).

Keywords: concept of race, natural history, anthropology, ethnography, ethnology

\section{Wprowadzenie}

Pod koniec XVIII w., obok tradycyjnych opartych na Biblii ujęć, pojawiły się w myśli polskiej nowe wyobrażenia, które wyjaśniały kwestie związane z geneza, historią i natura człowieka na podstawie badań przyrodoznawczych, historycznych, filozoficznych, filologicznych i wyłaniającej się $z$ historii naturalnej antropologii. Rozpoczął się proces formowania nowego podziału nauk, których głównym przedmiotem zainteresowań był gatunek ludzki w różnych aspektach jego natury, 
pochodzenia, zróżnicowania i miejsca w świecie organicznym. W Europie jeszcze w połowie XVIII w. historię naturalną traktowano jako przynależną do nauk historycznych (np. podział nauk historycznych Johanna Gatterera). Jednak pod wpływem idei europejskiego oświecenia i rozwoju przyrodoznawstwa nastapiło wyodrębnienie z obszaru nauki historycznej pola badawczego historii naturalnej (Lelewel 1826, ss. 12-13). W kolejnych dziesięcioleciach, gdy formacja panującą był romantyzm, doszło do wydzielenia nowych specjalizacji w ramach uprawianych nauk (historii i historii naturalnej). Nastapily zmiany w postrzeganiu zakresu problemowego poszczególnych dyscyplin i ich roli w wyjaśnianiu nadrzędnych zagadnień. Choć nowe kierunki badań, jak etnografia, etnologia, antropologia w połowie XIX w. miały nadal nieustabilizowane, zmieniające się znaczenia, to prześledzenie różnorodnych stanowisk ówczesnych autorów (przedstawicieli historii naturalnej, zoologów, lekarzy, historyków, filozofów, antropologów, badaczy języka) pozwoliło dostrzec wzajemne powiązania i różnice w teoretycznych założeniach oraz proponowanych metodach i wyodrębnić kolejne etapy w procesie kształtowania się nowoczesnych nauk o człowieku od drugiej połowy XVIII w. do początku lat 60. kolejnego stulecia, gdy antropologia stała się na ziemiach polskich dyscypliną akademicką ${ }^{80}$, a przegrane powstanie styczniowe doprowadziło do znaczących przewartościowań w myśleniu o narodzie i etniczności. W kontekście ogólniejszym była to epoka przed Darwinowskim przełomem. W 1859 r. twórca ewolucjonizmu opublikował pracę O powstawaniu gatunków, która na ziemiach polskich zaczęto popularyzować dopiero w latach 1863/1864 w formie wykładów w Szkole Głównej Warszawskiej czy artykułów prasowych.

Celem artykułu jest uchwycenie okresu poczattkowego, w którym myślenie o rodzaju ludzkim zaczęło nabierać w piśmiennictwie polskim nowego znaczenia opartego na naukowych podstawach oraz prześledzenie zmian w wyobrażeniach w kolejnych dziesięcioleciach, co zaowocowało wyodrębnieniem się antropologii, etnologii i etnografii. W sposób symboliczny przyjęto, iż zakres chronologiczny badań obejmie okres od momentu ukazania się pierwszej całościowej klasyfikacji gatunku ludzkiego Karola Wyrwicza z 1770 r. do kończącego analizowaną epokę podziału rasowego Antoniego Wagi z 1859 r. Zastosowane

${ }^{80}$ O rozpoczęciu w 1856 r. kursu antropologii na Uniwersytecie Jagiellońskim, zob. Bielicki, Krupiński, Strzałko 1987, ss. 4-5. 
kryteria dobru źródeł wiążą się z kilkoma istotnymi przesłankami. Należało dobrać zestaw materiałów źródłowych, który pozwoliłby na przeprowadzenie spójnej analizy, a jednocześnie był reprezentatywny dla polskiej refleksji w omawianym zakresie. Uwzględnione zostały poglądy uczonych oraz autorów spoza świata nauki, tych, którzy mieli znaczący wpływ na kształtowanie opinii publicznej (poprzez edukowanie, publikacje), ale i postaci mniej znanych, popularyzujących osiągnięcia „klasyków”. W epoce, z której pochodzą analizowane źródła, nie istniały jeszcze formalne podziały nauk o człowieku i nie zawsze rozgraniczano autorów ze względu na ich specjalizacje „zawodowe”. Role piszących niejednokrotnie nakładały się - rola badacza z misja ideologa czy publicysty (np. publikacje Andrzeja Kucharskiego cenne naukowo ukazywały się w formie popularnych listów z podróży). W artykule starano się w taki sposób dobrać opracowywany materiał źródłowy, aby wykazać odmienność poglądów głoszonych w ramach poszczególnych formacji umysłowych - cech właściwych dla myślenia o „rasie” z perspektywy oświeceniowej i romantycznej. Przy doborze uwzględniono także specyfikę terytorialną, starając się skompletować zestaw źródłowy z ziem trzech zaborów oraz emigracji. Ponadto ograniczono się wyłącznie do tekstów pisanych w języku polskim, z pominięciem polskich autorów publikujących w innych językach, przy założeniu, że granice świadomościowe były wyznaczane przez język piszących w ramach danej kultury etnicznej. Analizie zostały poddane zarówno wydawnictwa zwarte, w tym prace z zakresu historii naturalnej, podręczniki do zoologii, geografii, historii, prace popularyzatorskie, jak i periodyki o różnorodnych profilach.

W artykule pojęciem przewodnim, na którym skupiono uwagę jest rasa ludzka rozumiana jako wyodrębniona grupa ludzi o swoistym zespole cech fizycznych i kulturowych. Specyfika polskiego piśmiennictwa obu epok była duża dowolność w nazywaniu i opisywaniu pojęć związanych z podziałami ludzkości oraz wykorzystywanie tego samego terminu w różnych kontekstach. Bez wątpienia głównym powodem nieścisłości i polisemii był brak wypracowanej terminologii naukowej w dyscyplinie, która, jak już wspomniano, dopiero zaczynała się rozwijać. Niepopularność samego pojęcia „rasa” wynikała z przekonania, że jako słowo obce, niezrozumiałe dla polskiego odbiorcy lepiej zastępować rodzimym leksemem w rodzaju pokolenie, plemię, odmiana itd. Termin „rasa” w znaczeniu antropologicznym w polskich opracowaniach 
naukowych pojawił się dopiero w latach 20. XIX wieku ${ }^{81}$. Użył go po raz pierwszy Walenty Majewski, członek warszawskiego TPN, podając jego opis i podkreślając obce pochodzenie. „Rassa (races) czyli plemię” (w innym miejscu ,wielkie plemię”) dzieli się na szczepy, które mieszały się na przestrzeni wieków aż do powstania współczesnych narodów (Majewski 1827, s. 53; 1828, s. 256). Dopiero pod koniec analizowanej epoki termin „,rasa ludzka” był częściej stosowany.

\section{U progu nowoczesnych nauk o człowieku}

W typowym dla ujęć z drugiej połowy XVIII w. podejściu kreacjonistycznym, stworzenie świata i pierwsze okresy dziejów ludzkości prezentowano ściśle według przekazów biblijnych - Bóg wykreował świat „jednym słowem”, stworzył pierwszych ludzi Adama i Ewę. Potomstwo Kaina i Seta, odstępując od praw Boga, zostało ukarane potopem. Mitem biblijnym o wędrówce potomków Noego tłumaczono rozproszenie początkowo skupionych w jednym miejscu ludzi i powstanie „narodów” w różnych częściach świata (Wyrwicz 1787, ss. 4-28; Marczyński 1817, s. 3). Adam Naruszewicz, wyjaśniając najdawniejsze dzieje mieszkańców, z których w okresie późniejszym uformował się „,naród polski”, także nawiązywał do biblijnej tradycji - przodkowie Polaków „zostali przyprowadzeni” przez inne wędrowne plemiona „z Arki Noego” (Naruszewicz 1824, s. 4). Odmienności natury fizycznej, jak np. czarny kolor skóry również wyjaśniano w oparciu o przypowieść o Chamie.

Wraz z upowszechnieniem się idei oświeceniowych i kształtowaniem nauk, których tematyka nie ograniczała się do analizy źródeł biblijnych i teologii rosło zainteresowanie człowiekiem w nowym ujęciu. Poszukiwano świeckiego poglądu, który wyjaśniałby kwestie pochodzenia i zróżnicowania ludzkości w racjonalny sposób ${ }^{82}$. W pierwszych pol-

${ }^{81}$ W okresie wcześniejszym słowo „rasa” zastępowano wyrazami: „plemię”, „,ród”, „pokolenie”, „gatunek”, ,postać” albo traktowano opisowo: „różnice w kolorach ludzkiej skóry”, „barwy przyrodzone obywateli świata” (Wyrwicz 1770; Śniadecki, 1811; Jundziłł 1807, Kuberski 1817; Jasiński 1818 i in.).

${ }^{82}$ Istotny wpływ na poszukiwanie pozateologicznego wyjaśnienia pochodzenia człowieka miało wypracowanie krytycznych metod interpretacji Biblii w latach 80 . XVIII w. na uniwersytetach niemieckich. O paradygmacie biblijnego krytycyzmu w kontekście rozwoju historiografii pisze A. Tucker (2009, ss. 68-71). Krytykę źródeł, 
skich opracowaniach z zakresu historii naturalnej próbowano łączyć nowoczesne podejście inspirowane europejskimi osiagnięciami naukowymi z tradycją biblijną. W kreacjonistycznym ujęciu Krzysztofa Kluka, wykładowi z zakresu systematyki zwierząt towarzyszyła wiara w Boski plan stworzenia świata i biblijne wątki związane $z$ wieżą Babel i pomieszaniem języków (1809 [1779]). Autor, zachowując Linneuszowy podział „królestwa” zwierząt, nie zagłębiał się w klasyfikacje naturalistów, ale traktował historię naturalną z perspektywy jej użyteczności dla potrzeb człowieka. Podobnie w pierwszym w języku polskim podręczniku do zoologii autorstwa Pawła Czempińskiego, doktora medycyny i zoologa, przy współudziale Krzysztofa Kluka, zwierzęta zaprezentowano przede wszystkim jako istoty podległe i przydatne człowiekowi (1789). Inaczej jednak niż we wcześniejszym opracowaniu Kluka, podkreślono rolę znanych badaczy europejskich (J. Klein, R. Réaumur, G. Leclerc, Ch. Bonnet, L. Spallanzani), na osiagnięciach których oparto podręcznik. W późniejszych opracowaniach powoływanie się na autorytety w dziedzinie historii naturalnej stało się norma. Nazwiska uczonych, na których opierano podziały „rodu ludzkiego" na odrębne rasy, powtarzały się, tworząc kanon badaczy uznanych w polskiej literaturze przedmiotu za obowiązujący. Obok systemu Linneusza, od którego zawsze rozpoczynano rozważania, przywoływano najczęściej klasyfikacje J. Blumenbacha, G. Cuviera, A. Dumérila i J. Lamarcka (Jarocki 1821, ss. 11-20).

W przedstawieniach z drugiej połowy XVIII wieku (i wcześniejszych) obowiazzywała geografia i chronologia biblijna. Bóg stworzył człowieka i umieścił go w raju około roku 4104 przed Chrystusem (Lubieński 1740, s. 6), czy w innym opracowaniu 4004 przed Chrystusem (Wyrwicz 1787, ss. 4-5). Starotestamentowy raj umiejscawiano na obszarze Mezopotamii, skąd ludzkość rozproszyła się po całej Ziemi (Lubieński 1740, s. 568).

Obok elementów religijnych, utylitaryzmu w podejściu do świata organicznego i powierzchownego traktowania nowych systemów naturalistów, inną znamienną cechą pionierskich ujęć z zakresu historii

w tym ksiąg świętych i dzieł starożytnych, uprawiano także we Francji, gdzie wypracowano metodę krytyki źródłowej poprzez odrzucenie wszelkich faktów i zjawisk, których nie sposób wyjaśnić naukowo (Voltaire). 
naturalnej było podkreślanie istnienia jednego gatunku ludzkiego zróżnicowanego na odmiany ze względu na kolor skóry, kształt czaszki czy budowę ciała. Jednocześnie podważano dawniejsze przekazy o zamieszkiwaniu Ziemi przez ludzi np. bez głów, jednookich czy niebotycznych olbrzymów, które traktowano w kategorii bajek i „urojeń” (Kluk 1809, s. 58; Nowy Buffon 1806, ss. 11-18).

\section{Nauki o człowieku w okresie dominacji myśli oświeceniowej}

Badania nad „rodem ludzkim” z perspektywy biologicznej wchodziły w zakres historii naturalnej, nauki obejmującej zarówno obiekty przyrody ożywionej, jak i nieożywionej. W naukowym, jak i popularnym ujęciu złożona z trzech „królestw”: mineralogii, botaniki, zoologii „tworzy porządek systematyczny wszystkich tworów ziemskich" (Sołtyk 1798, s. 54; Jasiński 1818, s. 9; Kuberski 1817, ss. 3-4). Człowiek, przynależący do świata zwierzęcego, stanowił przedmiot badawczy zoologii, początkowo nazywanej „zwierzętopismem” (Czempiński 1789). Próbowano wypracować i ujednolicić naukową nomenklaturę oraz systemy, które miały porządkować i hierarchizować różnorodny świat bytów organicznych (Jundziłł 1805; Waga 1819). Utrzymywano Linneuszowy podział „królestwa” zwierząt na sześć klas. Człowiek przynależał do klasy „zwierząt ssących”, „rzędu naczelnych” (Jasiński 1818, ss. 6-7, 118; Jarocki 1821, ss. 7-11), w którym zajmował pierwsze miejsce „króla zwierząt” (Jundziłł 1807, ss. 12, 19-20), „czoło i najwyższy szczebel” (Śniadecki 1811, ss. 34, 47), a nawet ogniwo pośrednie ,między Aniołami a Zwierzętami, mając z pierwszymi rozum, z drugimi zmyślność i ciało" (Kluk 1809, s. 54). Wyraźnie zastrzegano, że mimo podobieństw anatomicznych rodzaj ludzki jest odrębnym bytem ze względu na właściwe tylko jemu cechy, jak objętość mózgu i odpowiednio obszerna czaszka (Śniadecki 1811, s. 45). To rozum „wznosi człowieka nad wszystkie zwierzęce stworzenia, i daje nad nimi panowanie" (Jundziłł 1807, s. 12). Ważnym wyróżnikiem była zdolność mowy jako cecha właściwa wśród zwierząt tylko ludziom oraz „doskonałość” budowy ciała (Jasiński 1818, s. 94; Jarocki 1821, ss. 71-73).

Wśród autorów z kręgów uniwersyteckich, zajmujących się zagadnieniami z zakresu antropologii, w tym wczesnym okresie najliczniejsza grupę, obok zoologów (np. F. Jarocki z Uniwersytetu Warszawskiego, 
S. Jundziłł z Uniwersytetu Wileńskiego), stanowili lekarze (np. P. Czempiński z Warszawskiej Szkoły Anatomii i Chirurgii, J. Śniadecki z Uniwersytetu Wileńskiego). Wskazywano, iż do całkowitego poznania człowieka, jego natury i zróżnicowania rasowego w obrębie gatunku, potrzebne są nauki medyczne w tym anatomia, fizjologia oraz patologia. W typowej charakterystyce $z$ epoki, ogólnym badaniem ciała ludzkiego zajmowała się anatomia, podczas gdy fizjologia skupiała się na funkcjach i czynnościach organizmu, a nauka o człowieku w stanie chorobowym to patologia. W przedstawieniu Jędrzeja Śniadeckiego, czołowego kreatora wczesnej antropologii polskiej, dopiero ze wszystkich tych umiejętności rodzi się sztuka lekarska (1811, ss. 37-40). W innym podziale w zakres „nauki przyrodzonej” wchodziły „historia naturalna właściwa" (budowa zewnętrzna człowieka), anatomia (budowa wewnętrzna), „fizjologia empiryczna” (funkcje organiczne) oraz „patologia” (stany chorobowe tych funkcji). Natomiast naukę o "zboczeniach" w ludzkiej budowie nazywano "historią potworów” (Podział nanki prayyrodzenia 1819, ss. 21-22). Znajomość medycyny miała unaukowić wszelkie spekulacje na temat zróżnicowania ludzi, gdy poszukiwano racjonalnego wyjaśnienia przyczyn powstania cech fenotypicznych u poszczególnych ras ludzkich. Jak powtarzał za Albrechtem Hallerem Stanisław Jundziłł, „siedlisko czarnej farby u Murzynów”, „miedzianej czy kasztanowatej” u innych ras może mieścić się w „tkance szlamowatej”, która znajduje się pod powierzchnią skóry (Jundziłł 1807, s. 25).

Jednak, jak utrzymywano, aby dogłębnie poznać i opisać rodzaj ludzki medycyna potrzebowała pomocy psychologii, która bada umysł człowieka, a zatem, jak wierzono, związek jego duszy z ciałem. Dlatego psychologię zaliczano do nauk metafizycznych, ale spokrewnionych z medycznymi. Józef Jasiński, dr medycyny i filozofii, absolwent Uniwersytetu Wileńskiego, krytycznie oceniał badania części lekarzy-fizjologów opierających się na kryterium fizycznym z pominięciem metafizyki. W jego ocenie błędem było interpretowanie możliwości umysłowych człowieka jedynie opierając się na cechach fizycznych (kształt czaszki, wielkość mózgu), gdyż zdolności umysłu w większym stopniu zależą od duszy. Dusza ludzka, argumentował, doskonalsza od ciała znajduje się w głowie - ale to nie mózg w czaszce osadzony „myśli”, ale dusza, która ma w mózgu „stolicę”. Dlatego radził podchodzić do zagadnienia kompleksowo, łącząc badania nad fizycznością z duchowością, ciało z duszą (Jasiński 1818, ss. 11, 58-60, 
$71,100)^{83}$. Pogląd ten stanowił jedną z pierwszych krytyk frenologii Franza Galla, które w polskiej refleksji romantycznej stały się tendencją powszechną. W polskim środowisku lekarskim zdecydowanej krytyce poddano także założenia romantycznej medycyny niemieckiej, która na uniwersytetach u naszych zachodnich sąsiadów obowiązywała niepodzielnie w latach 1797-1848. O niemieckim standardzie opartym na metafizycznych i filozoficznych spekulacjach oraz przyczynach jego odrzucenia przez polskich uczonych pisze obszernie Bożena Płonka-Syroka (2007; 2015). Obok względów religijnych, politycznych i praktycznych (rażąca nieskuteczność medycyny romantycznej) wpływ na ten stan rzeczy miało silne osadzenie uczelni polskich w kulturze umysłowej oświecenia. Na uniwersytetach w Warszawie, Wilnie i Krakowie podstawą nauczania był natomiast europejski standard kliniczny. $\mathrm{Na}$ odrzucenie założeń niemieckiej medycyny romantycznej przez polskie elity znacząco wpłynęły także autorytety ze świata medycznego z Wilna: J. Śniadeckiego i Josefa Franka, których poglądy i osiagnięcia wyznaczyły standard kliniczny medycyny polskiej w XIX w. (Płonka-Syroka 2015, ss. 113-116; 2007, ss. 445-459).

Natomiast antropologia w tym okresie była zaledwie nowym polem badawczym, jeszcze w polskiej nauce słabo rozpoznanym, opartym na zachodnioeuropejskich inspiracjach. W opisie J. Śniadeckiego „nauka o człowieku" powinna uwzględniać wszystkie aspekty jego natury i kultury - cechy biologiczne i umysłowe, miejsce w świecie organicznym oraz doskonalenie się przez związki społeczne (Śniadecki 1811, ss. 35-36, 42). Podobnie w definicji J. Jasińskiego, antropologia, którą wileński lekarz - podobnie jak wcześniej holenderski uczony Petrus Camper - wyodrębnił z historii naturalnej, jest ,nauką o własnościach człowieka fizycznych i moralnych, ukazujących dostojność jego wyniesiona nad wszystkie jestestwa fizyczne” (Jasiński 1818, s. III) ${ }^{84}$. Według autora pierwszego w języku polskim podręcznika antropologii przedmiotem badawczym nowej nauki jest człowiek w jak najszerszym kontekście obejmującym ,stan człowieka naturalny usadowiony na świecie fizycznym i moralnym; przyrodzenie jego co do początków, z których

${ }^{83}$ Pogląd umiejscawiający duszę w mózgu był powszechny (Kluk 1809, s. 55; Czempiński 1789, ss. 45-46; Jundziłł 1807, s. 11).

${ }^{84}$ O Jasińskim szerzej S. Gronkiewicz (1987). 
się składa; władze jego wyższe i niższe; tudzież przeznaczenie jego wysokie Boskim objawieniem ukazane" (Jasiński 1818, s. 115).

Typowy dla myślenia oświeceniowego był pogląd o dominującym wpływie klimatu na wygląd, usposobienie, zachowania i obyczaje ludzkich populacji czy ukształtowania terenu na ich stan umysłowy. Tłumaczono, iż nie sposób poznać natury człowieka, jego miejsca na Ziemi i zróżnicowania w obrębie gatunku bez znajomości uwarunkowań geograficznych, w których żyje. Zatem kolejną z nauk, której jednym z przedmiotów zainteresowań był człowiek nierozerwalnie związany ze środowiskiem naturalnym, była geografia. W ujęciu Karola Wyrwicza, rektora Collegium Nobilium w Warszawie, ,geografia naturalna” opisuje nie tylko powierzchnię ziemską jako dzieło natury bez przeobrażeń dokonanych przez człowieka - lądy, wody, wyspy, ale i „postaci ludzkiej kształt, twarzy barwę, język" (Wyrwicz 1770, ss. 2-3). Wyrwicz był autorem najstarszej oświeceniowej klasyfikacji gatunku ludzkiego jeszcze przed Blumenbachowskiej, w której podzielił ludzkość na cztery typy rasowe nazwane „postaciami”: afrykańską, chińska, lapońska, europejską (Wyrwicz 1770, ss. 40-42). Zasadniczym kryterium różnicującym był zestaw cech fizycznych traktowanych równorzędnie: kolor skóry, kształt twarzy, nosa, włosy i zarost oraz wzrost i budowa ciała. Jak wskazują określenia zastosowane w nazwach wyodrębnionych ras fundamentalnym wyznacznikiem był czynnik geograficzny, czyli główny obszar pochodzenia i osiedlenia danej populacji.

Obok geografii, historia - opisująca i wyjaśniająca dzieje rodzaju ludzkiego od jego zarania - wchodziła w skład dyscyplin naukowych, których przedmiotem zainteresowań był człowiek ujmowany jako istota społeczna. W ujęciu J. Śniadeckiego człowiek w stanie dzikim, jeszcze niezmieniony przez cywilizację i związki towarzyskie, nie różnił się specjalnie od zwierząt, najwyżej zewnętrznymi cechami - jest „,surowy”, zbliżony do rodzaju małp bezogonowych, o nieznacznych władzach umysłowych i „duszy uśpionej”. Dopiero bowiem związki społeczne i wychowanie powoduja jego przebudzenie z „letargu”. Jednak nawet w tej „surowej” formie, zdaniem wileńskiego uczonego, widoczne są przejawy jego późniejszej wielkości (Śniadecki 1811, ss. 41-42). Według Hugona Kołłątaja, rektora krakowskiej Szkoły Głównej Koronnej człowiek od początku był istotą społeczną, potrzebującą do zaspokajania potrzeb pomocy innych. Toteż idea społeczności wypływa „z ustawy przyrodzenia koniecznej i nieodmiennej” (Kołłątaj 1842, s. 288). 
Popularnym w tym okresie roztrzasaniom historycznym i językowym nad pierwotnym pochodzeniem plemion towarzyszyła ogólniejsza refleksja nad rasami ludzkimi i ich zróżnicowaniem. Wawrzyniec Surowiecki, wykładowca Szkoły Głównej Prawa i Administracji w Warszawie, poszukując genezy Słowian wyodrębnił cztery ,rody” w gatunku ludzkim, które różniły się zbiorem stałych cech natury fizycznej: „,ród Mongołów”, „właściwy ród Indian”, „rody, które nazywamy murzyńskimi” oraz „rody Europejskie” (Surowiecki 1824, ss. 66-67).

Nauki filologiczne i językoznawstwo porównawcze wymieniano jako pomocnicze do wyjaśnienia pokrewieństwa/różnic ludzkich populacji czy wielkich procesów, jakimi były wędrówki ludów z Azji do Europy $^{85}$. Badania nad geneza i historią ludów prowadzono poprzez wyodrębnienie najdawniejszych wyrazów z ich języków i ustalenie późniejszych zapożyczeń. Prześledzenie ,pierwiastkowych znaków” pozwalało odtworzyć wyobrażenia w początkach organizowania się ludzkich społeczności. Jak tłumaczył Walenty Majewski, chodziło o stworzenie inwentarzy zbiorowych znaków, myśli i pojęć poprzez połączenie dociekań filologicznych z badaniami nad religia ludów. Proponowana przez niego metoda oparta na analizie wyznaczników kulturowych miała lepiej wyjaśnić kwestie pochodzenia ludów niż „wyciski ich fizyczne i moralne" (Majewski 1827, ss. 127, 181-182). Podobnie w ocenie Jana Kossakowskiego, przy ustalaniu pokrewieństw między plemionami cechy fizyczne były mniej znaczące niż wyznaczniki kulturowe. Choć można dostrzec podobieństwo rysów między ,pobratymczymi” ludami, to najistotniejsze jest, gdy ,skłonności i przymioty, jedność obyczajów, jeden ród ludzki, jeden i tenże sam szczep okazuje" (Kossakowski 1804, ss. 18-21). Wielkie znaczenie badaniom filologicznym w rozważaniach nad genezą plemion nadawał także W. Surowiecki (1822; 1824). Ten kierunek myśli uznający wyższość kultury nad biologią albo przynajmniej równorzędność obu kategorii z powodzeniem rozwijany w ramach formacji romantycznej nie był typowy dla oświecenia. W epoce fascynacji natura i biologicznym aspektem człowieczeństwa intensywniej rozwijał się dyskurs o zróżnicowaniu fizycznym rodzaju ludzkiego i przyczynach powstania odrębnych odmian rasowych przy fundamentalnym

85 O wpływie językoznawstwa porównawczego na wyłonienie się biologii ewolucyjnej, gdy dostrzeżono analogię między językami a gatunkami i o wpływie Systema Naturae Linneusza na językoznawstwo zob. Tucker (2009, ss. 75-84). 
założeniu o istnieniu jednego gatunku i „przyrodzonej równości” w obliczu Boga wszystkich ludzi niezależnie od płci, stanu społecznego, koloru skóry czy obszaru zamieszkania.

\section{Kontynuacja i zmiany po 1831 roku}

W pierwszej połowie XIX w. nauki o człowieku wyspecjalizowały się w sposób szczególny w klasyfikacji różniących się odmian w gatunku ludzkim. Ten model nauki opierał się na wyszukiwaniu określonych cech, różnic i podobieństw, które nie były tylko powierzchowne, dostrzegalne na pierwszy rzut oka, ale przede wszystkim tych wymagajacych pogłębionych i żmudnych badań porównawczych spreparowanych okazów czaszek, szkieletów, wewnętrznych narządów. Mistrzowie konstruktorzy tego modelu jak Cuvier czy Blumenbach mieli szczególną umiejętność poszukiwania wyróżniających znamion w ramach gatunku i tworzenia koherentnych typów fizycznych w zastosowaniu metod anatomii porównawczej i kraniologii. Jak opisuje kontekst rodzącej się antropologii jako nauki o społeczeństwach „prymitywnych”, pozaeuropejskich Hanna Schreiber: „wiek XIX był okresem kumulowania, klasyfikowania i hierarchizowania wiedzy o świecie, zwłaszcza tym Nowym, i podbijanych „Innych”. Wiedza o „Innych”, jak każda wiedza, musiała zostać uporządkowana, pogrupowana, poddana klasyfikacjom i hierarchizacji”' (Schreiber 2013, s. 202). Z tej perspektywy, w kontekście epoki - jej wyobrażeń, stanu wiedzy czy ogólnej sytuacji, w jakiej kształtowały się nauki o człowieku, należało wyjaśniać proces ich wyodrębniania się i specyfikę.

Polityczne reperkusje po upadku powstania listopadowego na ziemiach zaboru rosyjskiego znacząco wpłynęły na dalszy rozwój nauk. Likwidacji uległy instytucje naukowe, jak przodujący w zakresie historii naturalnej i historii Uniwersytet Wileński, Towarzystwo Warszawskie Przyjaciół Nauk i Uniwersytet Warszawski. Wśród nielicznej grupy badaczy zajmujących się naturą człowieka i jego zróżnicowaniem fizycznym prym wiedli zoolodzy i reprezentanci nauk medycznych ${ }^{86}$.

${ }^{86}$ Po rozwiązaniu uczelni wielu profesorów i adiunktów borykało się z problemem nowego zatrudnienia. W Wilnie i Warszawie radzono sobie szukając pracy w szkolnictwie na poziomie gimnazjalnym, jako prywatni nauczyciele, w towarzystwach czy wydawnictwach. W Krakowie problematykę antropologiczną rozwijano w powstałym 
W tym aspekcie można mówić o kontynuacji zarówno pod względem profesji autorów, jak i ujmowania zakresu problemowego nauk o budowie i funkcjonowaniu człowieka. W badaniach nad biologicznym zróżnicowaniem gatunku ludzkiego, podobnie jak w refleksji oświeceniowej, powoływano się osiągnięcia anatomii, fizjologii i patologii (Encyklopedia Powszechna t. 4, 1839, s. 664). Kategorie obowiązujące przy taksonomii zwierząt pozostały bez zmian (Kumelski, Górski 1836, s. 18; Waga 1859, ss. 11-12). „Zwierzęta ssące”, na czele których sytuowano człowieka, to „wyższe ciała organiczne” dzielące się na rzędy, familie, rodzaje i gatunki, a naukę opisującą systematykę ssaków nazywano mammologią (Pietruski 1853, s. VI). Nie było także rewolucyjnych zmian w układzie systematycznym świata zwierzęcego, przy czym Linneuszowy podział uznawany za pierwotny zastępowano nowszymi, w oparciu o późniejsze osiagnięcia G. Cuviera, J. Blumenbacha, J. Vireya.

Jednak romantyczna formacja umysłowa przewartościowała myślenie o człowieku przynosząc nowe trendy i odmienne od oświeceniowego podejście. Wszystko to, co duchowe było z założenia wyższe niż to, co materialne, a zatem różnice fizyczne między populacjami miały w tym oglądzie mniejsze znaczenie. Poszerzył się krąg autorów zainteresowanych refleksją nad rodzajem ludzkim, przy czym akcent przeniósł się zdecydowanie z biologii na sferę kultury. Człowiek, choć nadal dwupierwiastkowy, interesował romantycznych autorów przede wszystkim jako istota duchowa, podobnie jak wspólnota narodowa czy plemienna, w której nadrzędną rolę odgrywał duch samoświadomy i jednoczący jednostki wokół pokrewieństwa w myśleniu, wyobrażeniach, odczuwaniu, języku. Biologiczne więzi miały drugorzędne znaczenie, stąd i podziały ze względu na fizyczne cechy były przez tę grupę twórców lekceważone. Pisarze, publicyści, ale także historycy i badacze literatury wypowiadali się na temat gatunku ludzkiego, jego pochodzenia, zróżnicowania fizycznego i kulturowego - z zaznaczeniem, że te ostatnie są istotniejsze - przyczyniając się do wyłonienia z nauk przyrodzonych nowych specjalności o bardziej humanistycznym charakterze.

Stopniowo więc, pod wpływem rozwoju wiedzy przyrodoznawczej i humanistycznej, wyodrębniły się nowe kierunki i obszary badań, które

w 1815 r. Towarzystwie Naukowym Uniwersytetu Krakowskiego, w którym działał Józef Majer. Z jego inicjatywy rozpoczęto w 1856 r. kurs antropologii na UJ, a w 1874 r. powołano Komisję Antropologiczną Akademii Umiejętności. 
wcześniej wchodziły w zakres historii naturalnej i historii. Nadal jednak granice między nimi były mało wyraziste, a zakresy dociekań badawczych pokrywały się. Na przykład, w niektórych opracowaniach utożsamiano antropologię z etnologią lub etnologię z etnografią (Jasiewicz 2010, ss. 210-211). Pojawiły się też nowe podejścia w ramach już uprawianych nauk. Napływ idei formacji romantycznej, z jej fascynacją historyzmem, narodowością oraz, jak już wspomniano, duchowym wymiarem człowieka i tworzonych przez niego społeczności, zmienił zakres zainteresowań badawczych. Nowe elementy widoczne są już w opisie zastosowania antropologii w badaniach grup ludzkich Joachima Lelewela z 1815 r. Obok analizy cech zewnętrznych historyk wileński podkreślał równorzędność badań nad językiem, religia, wyobrażeniami i zbiorowym charakterem. „Antropologicznie czyli etnologicznie poznają się związki w uwadze na kształt i skład fizyczny, na języków naturę, na religie i różne mniemania w spadku od przodków pozostałe, stopień doskonalonych sił ciała i duszy, postęp słowem w doskonałości, władze umysłowe i charakter narodowy, co daje poznać zdolności i skłonności narodów, wskaże przyczyny często niewyraźne, na jakich zasadach stoją ich związki, wzajemne stosunki, do czego są usposobione, w jakim położeniu i jakich pomyślności doświadczyć moga" (Lelewel 1815, ss. 34-35). W późniejszym o dekadę opracowaniu Lelewel nie traktował już synonimiczne antropologii i etnologii, a tę pierwsza zajmująca się poznaniem fizycznym i moralnym człowieka - zaliczył do nauk pomocniczych przy analizach historycznych, która jednak w obręb historii nie może być wciągana „pod żadnym pretekstem” (1826, s. 53). W późniejszym ujęciu encyklopedycznym antropologię definiowano jako ,naukę o człowieku, fizyczną i umysłową naturę jego objaśniająca”, która niedawno odłączyła się jako „nauka natury człowieka” od jego historii naturalnej. Jej przedmiot badawczy był różny w zależności czy bardziej zajmuje się fizyczną (,antropologia fizyologiczna”) czy duchową (,,antropologia psychiczna”) stroną człowieka lub też rozważa obie (,antropologia pragmatyczna”) (Encyklopedia Powszechna t. 2 1837, s. 162). W popularnym oglądzie uznawano ją za naukę wywodzącą się z „nauk przyrodzonych”, której przedmiotem badań były różnice rasowe w ludzkości (Kronika paryska 1857, ss. 155-159). To wczesne postrzeganie antropologii bardziej jako nauki o fizycznej naturze człowieka wynikało, jak współcześnie tłumaczy Zofia Sokolewicz, z dążenia obserwatorów do określenia nosicieli badanych kultur. „Stąd iunctim 
między rasą a kulturą”. Opisy „Innych” często rozpoczynano od najbardziej widocznych cech fizycznych przechodząc do charakterystyki obyczajów, języka, religii (Sokolewicz 2015, s. 21).

Rozmaicie postrzegano powiązania antropologii z innymi naukami. W ujęciu A. Wagi, jest ona związana zarówno z historią naturalną jak i naukami filozoficznymi, gdyż zajmuje się poznaniem człowieka nie tylko pod względem fizycznym, ale i moralnym (1859, s. 197). Z kolei Józef Kremer zaproponował interesujące rozumienie antropologii jako dziedziny ściśle powiązanej z psychologią. Przedmiotem psychologii jest „duch”, zaś antropologia bada wzajemne związki ducha (,,jestestwa świadomego”) z materią („potęga bezświadomą”). Zjawiska, które zachodzą w rezultacie tych relacji, wynikaja z wpływu cielesności na ducha, jak np. rasy ludzkie, temperament, wiek, płeć. W klasyfikacji Kremera zjawiska psychologiczne maja zatem naturę świadomą i nieświadomą, a zadaniem antropologii jest badanie zachodzących między nimi zależności i wpływów (Dobroczyński 2007, ss. 127-132). Pod koniec lat 40. XIX w., w ramach popularyzowania osiagnięć nauk zachodnich, pojawił się termin antropografii jako działu antropologii zajmującej się opisem podziału ludzkości na rasy (S. P. 1849, ss. 161-163).

Z historią i geografią ściśle łączyła się etnografia rozumiana jako nauka o ludach, ich pochodzeniu, podziałach i rozmieszczeniu (Lelewel 1826; Pol 1850; Rymarkiewicz 1849; Waga 1859). Jak ustalił Zbigniew Jasiewicz termin etnografia pojawił się w polskim piśmiennictwie w latach 1816-1817 w „Dzienniku Wileńskim”. W wytycznych dotyczących nauczania historii w szkołach, etnografia to jedna $z$ metod i nauk pomocniczych historii, a jej przedmiotem były badania nad narodami i ludami pozaeuropejskimi (Jasiewicz 2010a, ss. 41-42). W okresie późniejszym rozważano dalsze podziały, które miały na celu uporządkowanie terminologicznych nieścisłości. W jednym z uznanych opracowań etnogenia zajmowała się badaniami ogólnymi nad organizowaniem się człowieka w ,towarzystwa”, a w jej skład wchodziły etnografia, zajmujaca się rozmieszczeniem ,pokoleń” ${ }^{87}$ ludzkich w dziejach oraz etnologia, skupiająca się na badaniach różnic pomiędzy rasami (Waga 1859, s. 197).

Warto przytoczyć kilka przykładów z epoki dla ukazania różnic w podejściu autorów do opisu etnograficznego ludów w opracowaniach

\footnotetext{
${ }^{87}$ Waga stosował termin „pokolenie” na określenie rasy (Waga 1859, s. 194).
} 
o ambicjach naukowych. Podstawowym przedmiotem rozważań rozprawy A. Kucharskiego Etnografia Turków i ich pobratymców stanowiła przynależność rasowa Turków i pokrewnych ludów oraz ich rozmieszczenie, z uwzględnieniem pierwotnego pochodzenia i późniejszych obszarów zasiedlenia. Powołując się na badania Heinricha Berghausa stwierdzał, iż „Turcy stanowią przejście od naszego plemienia ludzi białych, inaczej kaukaskim zwanego, do plemienia żółtych czyli mongolskiego"88. Początkowo należeli do ,pięknego plemienia europejskiego białych Kaukazów”, ale przez wielowiekowe mieszanie się z rasą żółtą „pozostaja zwykle mocniejsze ślady tej ostatniej" (Kucharski 1854, s. 550). W ocenie tego znanego filologa, obok koloru skóry, równie istotnym wyróżnikiem, świadczącym o przynależności do np. „białego plemienia”, był język. Badanie dialektów „pokolenia”, w tym przypadku tureckiego, potwierdzało ich pierwotne wspólne pochodzenie, a z kolei różnice pozwalały uchwycić wewnętrzne podziały na szczepy i narody.

W ujęciu Franciszka Duchińskiego badania etnograficzne, czyli „opis ludów według ich pochodzenia" są najpewniejszym środkiem do prześledzenia życia dziejowego narodów (1859, s. 76-77). Z kolei badania logograficzne („opis ludów według języków”) prowadzi się w sytuacji, gdy niemożliwa jest analiza etnograficzna. Zatem, inaczej niż Kucharski, Duchiński wyraźnie zawężał opis etnograficzny do ustalania pochodzenia ludów ze względu na ich cechy fizyczne. Jak przekonywal, narody zmieniaja języki, obyczaje, religie. Nie można zmienić jedynie ,żywiołów swoich pierwotnych", które ludy otrzymały w podziale rodu ludzkiego na ,wielkie plemiona” (rasy). Dlatego: „dla badania tych żywiołów najznakomitsza nauka jest etnografia, która jest podstawą i dla badania rodu ludzkiego podług języków" (Duchiński 1859, s. 77). W ocenie autora należy obie nauki wyraźnie rozgraniczyć, a powszechne łączenie etnografii z logografią wynikało z faktu, iż etnografia była nowym obszarem badawczym.

W analizowanym okresie przeważał jednak postulat łączenia badań fizjologicznych z filologicznymi, gdyż, jak powtarzano, to właśnie ,język jest znamieniem wspólności rodu i pochodzenia, dowodem długiego życia w społeczeństwie samoistnym" (Piśmiennictwo džisiejsz̨e 1850, s. 55). W ujęciu Wacława Przybylskiego, przyrodnika i tłumacza,

${ }^{88}$ Kucharski niepopularny w Polsce termin „rasa” zastępował słowem „plemię”. Plemiona (rasy) dzieliły się na pokolenia, a te na szczepy (Kucharski 1854, s. 548). 
etnograf przy klasyfikowaniu narodów musi korzystać z ustaleń i metod innych nauk - aby określić wzajemne pokrewieństwo bada historię najdawniejszą, analizując łączenie się ludów, zwyczaje pierwotne i te przejęte od innych oraz poszukuje pokrewieństwa między językami. Druga stroną badań etnograficznych jest opisanie współczesnego stanu naro$\mathrm{du}$ - życia społecznego, stopnia wykształcenia umysłowego i rozwoju fizycznego. Zadaniem etnografii jest określenie roli każdego narodu/ ludu, nawet najmniejszej „hordy” w procesie ogólnego postępu. „Etnografia gatunkując ludzkie plemiona i ustawiając narody w nierozerwalnym łańcuchu, gdzie każdy zajmuje miejsce odpowiednie swojemu wykształceniu organicznemu, tworzy z całej ludzkości wielką rodzinę, której patriarchą jest plemię europejskie, a inne są dziećmi potrzebującymi ręki opiekuńczej” (W. P. 1852, ss. 11, 21-22) ${ }^{89}$.

Jan Rymarkiewicz, badacz literatury, historyk, traktujący etnografię jako „odnogę" geografii, zawężał jej przedmiot i metodę do opisu zewnętrznych cech i osobliwości pojedynczych narodów na wzór historii naturalnej. W jego ocenie nauce tej brakuje filozoficznych podstaw na podobieństwo związanej z historią historiozofii, a dane pozyskiwane w badaniach etnograficznych mają charakter wyłącznie empiryczny. Potrzebna była „filozofia etnografii”, która, wznosząc się na poziom ogólniejszy, podniosła by jej znaczenie w panteonie nauk (Rymarkiewicz 1849, ss. 6-7). Mimo różnic w określaniu zakresu i metod badań najczęściej powtarzanymi zadaniami etnografii było ustalenie pochodzenia i rozmieszczenia plemion/ras ludzkich na świecie, ich opisanie oraz przedstawianie także w formie graficznej (S. P. 1849, s. 163).

Kolejnym kierunkiem badań, związanym $\mathrm{z}$ poznaniem ludów w wymiarze historycznym i współczesnym, była zbliżona do etnografii etnologia, którą często łączono lub traktowano synonimicznie $z$ antropologia, a niekiedy postulowano jej wyodrębnienie. W wizji Rymarkiewicza powinna to być nauka ,udzielna”, badająca pojęcie narodowości, a przez to wypełniająca lukę pomiędzy pokrewnymi naukami etnografią a historiozofia. Zadaniem etnologii jako „filozofii etnografii” byłoby

${ }^{89}$ W. P. autor wstępu i tłumacz książki J. d'Omaliusa d'Halloya to najprawdopodobniej Wacław Przybylski (Jasiewicz 2010, s. 211). Jako słuchacz wykładów Pierre’a Flourensa, ucznia G. Cuviera z zakresu anatomii porównawczej w Narodowym Muzeum Historii Naturalnej w Paryżu (Daszkiewicz 2014, s. 105), miał on ku temu odpowiednie kwalifikacje. 
,z naturalistycznych i empirycznych materiałów etnografii, na drodze systematycznego badania i koniecznego rozumowania odsłonić normalną, organiczną Narodowości przyrodę; żeby wznieść się na stanowisko historiozoficzne i okazać we wszystkich narodowościach zastosowaną tę samą Narodowości budowę, ten sam organiczny proces jej życia i cel ostateczny" (Rymarkiewicz 1849, s. 7). Opisując jej strukturę wyodrębniał etnologię ogólną, skupiającą się na teorii oraz etnologię zastosowana, prezentująca indywidualne cechy narodowości, jej znamiona materialne (ziemia, dzieje) duchowe (język, literatura, sztuka) i osobiste (opis plemion i procesu ich zespolenia w naród) (tamże, ss. 9-15).

W humanistycznym oglądzie utrzymywano, że etnologia to nie tylko nauka o odrębnościach fizycznych ras ludzkich, ale także o ,anatomii porównawczej pod względem moralnym. Jakie któremu z plemion właściwe sa przymioty, albo wady!" (Kilka słów o etnologii 1850, s. 676). Autor artykułu krytykował podejścia naturalistów (Blumenbach, Cuvier), którzy analizy ras ludzkich ograniczali do cech fizycznych. Tymczasem przy ustalaniu pochodzenia każdej z pięciu ras i ich „odgałęzień” nadrzędnym przedmiotem badań powinny być pierwotny język, podania i obyczaje - to ,pierwiastkowe piętno wyobrażeń, zwyczajów i mowy”. Na podstawie przekształcających się brzmień i pojęć w różnych czasach i miejscach badacz może uchwycić zjawisko pierwotnej wspólności (tamże, ss. 677, 687).

W ogólnej ocenie reprezentanci nauk przyrodniczych i medycznych nieufnie traktowali spekulacje filozoficzne i historyczne, które dostatecznie nie uwzględniały biologicznych aspektów człowieczeństwa. Natomiast autorzy o ukierunkowaniu humanistycznym krytycznie spoglądali na zoologów i lekarzy, zarzucając im, iż koncentrują się wyłącznie na objawach zmysłowych, zmiennych i przypadkowych. Skupiając się na fizyczności człowieka, na różnicach dostrzeganych gołym okiem „nie wzniosą się do poglądu ogólnego, nie przyjdą nigdy do poznania istoty wszech rzeczy leżącej poza zmysłowością" (Piśmiennictwo dzisiejsze 1850, s. 31). W tym kontekście do wyjątków należała praca Stanisława Rzewuskiego, dra filozofii i filologa, który postulował prowadzenie, zaniedbanych w polskim środowisku naukowym, badań z fizjologii porównawczej nad zróżnicowaniem rasowym i etnicznym. Chodziło o wyodrębnienie ,znamion stanowczych, czyli prototypu każdego plemienia, rodu i ich odmian". Rzewuski dostrzegał potrzebę tworzenia obrazów graficznych, które ukazywałyby pochodzenie i naturę plemion 
oraz ich zmieszanie (na wzór map filologicznych). W jego opinii zastosowanie analiz z zakresu fizjologii porównawczej sprostowałoby wiele błędnych sądów o pokrewieństwie, pochodzeniu, wędrówce ludów, odkryło pierwotne siedliska (Rzewuski 1830, s. 11). Twierdził, iż porównywanie podobieństw mowy, obyczajów, nałogów itd. często zawodzi (podobne zatrudnienie i sposób życia nadaje osobnikom różnych plemion/ras cechy tożsame) i dlatego należy posiąść umiejętność dostrzegania podobieństw w rysach fizjologicznych (tamże, s. 12).

Natomiast założenia popularnej w innych krajach europejskich kraniologii nie znalazły w piśmiennictwie polskim uznania. Powszechnie krytykowano naukowe podstawy prac F. Galla, J. Spurzheima (1809) i ich następców, które uważano za podejście paranaukowe. Negowano pomysły, aby po budowie czaszki określać zdolności umysłowe, przeprowadzać szczegółowe wnioskowanie o wadach i zaletach ludzkiego rozumu. Wówczas kwestia zbadania istoty moralnej człowieka ograniczała by się do topografii jego czaszki i do wymiaru objętości i wyniosłości tzw. guzów zdolnościowych (Przybylski 1857, s. 305). Raczej należy skupić się na poznaniu i opisaniu cech rozumu (Wiszniewski 1988, s. 54) i wykazać ostrożność w podejściu do podobnych poglądów w nauce, aby nie zejść z drogi badacza w kierunku fantazji (Libelt 1844, ss. 4-5). F. Gall, przyznając „różnym wyniosłościom na czaszce wybitym odrębne władze, podzielił duszę na kawałki”, ale to tylko „piękne przewidzenie” (Dziekoński 1841, ss. 659-660). W obszernym artykule założenia kraniologów skrytykował W. Przybylski. „Teoria Galla jest dźwignią fatalizmu, przypuszcza ona pewna górującą namiętność w człowieku, panującą samowładnie, wobec której wola nic nie znaczy. Odbierając wolną wolę, ten najwyższy dar Stwórcy dla nas śmiertelnych, niszczy ideę zasługi i występku, bo gdzie nie ma woli, tam i zasługi być nie może" (Przybylski 1857, s. 303). Autor nie wróżył kraniologii przyszłości, gdyż, w jego ocenie, to teoria oparta na przypuszczeniach, które trudno zweryfikować, a metoda jest nieścisła (minimalna pomyłka przy pomiarach prowadzi do mylnych wniosków) (tamże, s. 307).

\section{Podsumowanie}

Okres poddany analizie to czas, gdy granice między naukami czy obszarami zainteresowań na temat człowieka, jego pochodzenia i zróżnicowania były niedoprecyzowane, odmienne u poszczególnych badaczy, 
z czego, jak podsumował J. Lelewel, wynikaja „dziwne definicje, niewłaściwe opisy, dowolne przypuszczenia" (1826, s. 36). Analiza materiałów źródłowych pozwoliła jednak na ukazanie, w tym chaotycznym obrazie, kolejnych etapów kształtowania się nauk o człowieku charakteryzujących się określonymi cechami. W pierwszym okresie w drugiej połowie XVIII w. powszechnie łączono naukę z teologią, wyjaśnienia racjonalne $z$ tradycją biblijna. Wszechobecny kreacjonizm narzucał gotową wizję genezy, natury i zróżnicowania ludzkości. Jednak pod wpływem idei oświeceniowych i wraz z rozwojem nauk przyrodniczych, historycznych, językoznawstwa i krytycyzmu biblijnego doszło na przełomie XVIII i XIX w. do stopniowego uwolnienia nauk spod religijnego determinizmu i wykształcenia świeckich podejść i wyobrażeń. W tym drugim okresie historia naturalna była już odrębną nauką z doprecyzowanym zakresem badań obejmującym, obok mineralogii i botaniki, zoologię, w tym naukę o człowieku ujmowaną z perspektywy biologicznej. Pojawiające się pierwsze i nieliczne opinie o antropologii opisywały ją jako naukę dopiero wyodrębniającą się z historii naturalnej, badającą człowieka zarówno w aspekcie fizycznym, kulturowym i społecznym. Trudno natomiast mówić o etnografii czy etnologii jako odrębnych naukach, o których mamy jedynie pojedyncze wzmianki zwykle w tekstach popularyzujących zachodnie osiagnięcia. Nieliczna społeczność badaczy skupiona przede wszystkim na uniwersytecie wileńskim zainicjowała badania nad człowiekiem w zakresie historii naturalnej. Był to znaczący ośrodek intelektualny, którego rozwój został gwałtownie przerwany. Jednak wpływ wileńskiego środowiska naukowego, z J. Śniadeckim na czele, na całokształt wczesnej antropologii był fundamentalny. Trzeci okres, określany przez historyków mianem międzypowstaniowego, kształtował się pod wpływem idei romantycznych, gdy nadrzędną wartością przenikającą niemal całą humanistyczną refleksję był naród ujmowany jako duchowa wspólnota myśli, uczuć i celu. Promowano pogląd o wyższości więzi umysłowych nad fizycznymi, zespolenia duchowego nad pokrewieństwem krwi, kultury nad biologią. Zmieniło się zatem spojrzenie na problematykę nauk o człowieku, gdy skupiono się nie tyle na klasyfikacjach naturalistów, ile na kwestiach związanych z umysłowością, rozwojem kultury i cywilizacji ludzkich społeczności. Natomiast w kwestii postrzegania natury ludzkiej w refleksji oświeceniowej koncentrowano się na cechach typowych dla całej ludzkości, podczas gdy zafascynowanych 
historią romantycznych obserwatorów interesowały bardziej jednostkowe wzorce związane $z$ konkretnym czasem i miejscem, pociagała różnorodność świata ludzkiego. Dlatego można uznać romantyków za protoplastów antropologii kulturowej. Uogólniając, stanowisko większości autorów w kwestii zróżnicowania rasowego ludzkości przedstawiało się różnie w zależności od czasu powstania koncepcji i wpływu na nią kultury umysłowej. W epoce oświeceniowej, hierarchizując gatunek ludzki, kładziono nacisk na jego biologiczne zróżnicowanie dokonane pod wpływem zmian środowiskowych. Romantyzm zwrócił się ku kulturze i duchowości człowieka. Pozytywizm natomiast, opierając się na osiagnięciach nauk przyrodniczych, w kryteriach biologicznych determinujących duchowość, kulturę i rozwój cywilizacyjny widział podstawę wartościowania grup ludzkich. W kontekście wpływów europejskiej antropologii na ukształtowanie się nowoczesnych nauk o człowieku na ziemiach polskich za najważniejsze należałoby uznać wpływy francuskie i niemieckie ${ }^{90}$. W szczegółowym ujęciu Paryż wyznaczał standardy w zakresie nauk przyrodniczych, zaś Wiedeń, Edynburg, a po $1848 \mathrm{r}$. także uczelnie niemieckie w dziedzinie medycyny.

Znamienną cechą ówczesnej refleksji, zwłaszcza od lat 30. XIX w., było postulowanie łączenia osiagnięć różnych nauk i metod w rozważaniach nad pochodzeniem człowieka i jego zróżnicowaniem. Podkreślano, że ustalanie pokrewieństwa/odrębności czy kolebki ludów wyłącznie na podstawie fizycznych podobieństw/różnic jest niemożliwe. Najlepsze efekty osiagnie się, łącząc studia nad fizjologią z badaniami filologicznymi, etnograficznymi i historycznymi (Chojecki 1846, s. 475,480 ; Rzewuski 1830 , s. 5). Nie oznacza to jednak, iż spoglądano z niechęcią na proces wyodrębniania się nauk, a wręcz przeciwnie dostrzegano w tym istotę postępu. W „pochodzie nauk widzimy to, iż przez rozdział onych na pojedyncze gałęzie wykształca się każda umiejętność z osobna i czyni wielkie postępy" (Pol 1850, s. 8). W ówczesnym paradygmacie naukowym badania nad naturą człowieka, jego geneza, zróżnicowaniem, rozmieszczeniem i historią wymagały więc połączenia rozmaitych metod, współpracy uczonych wielu nauk, ale bez utraty ich odrębności.

${ }^{90}$ Po 1848 r., gdy na niemieckich uniwersytetach odrzucono standard medycyny romantycznej, większość polskich studentów medycyny tam właśnie podjęła naukę (za: Płonka-Syroka 2015, s. 120). 


\section{6. Źródła finansowania artykułu}

Artykuł powstał w ramach projektu grantowego Narodowego Centrum Nauki nr 2016/21/B/HS3/03696.

\section{Bibliografia}

Bielicki, Tadeusz; Krupiński, Tadeusz; Strzałko, Jan 1987: Historia antropologii w Polsce. Przeglad Antropologiczny 53 (1-2), ss. 3-28.

Chojecki, Edmund 1846: Starożytności i dzieje czeskie. Biblioteka Warszawska 4, ss. $457-503$.

Czempiński, Paweł; Kluk Krzysztof 1789: Zoologia, czyli zumierz̨etopismo, dla sžkót narodonych. Warszawa: w Drukarni Nadwornej JKM i KEN.

Daszkiewicz, Piotr 2014: Znaczenie nauczania w Narodowym Muzeum Historii Naturalnej w Paryżu dla polskiej nauki okresu zaborów. Nauka Polska. Jej Potrzeby Organizacja i Roźwój 23 (48), ss. 103-110.

Dobroczyński, Bartłomiej 2007: Józefa Kremera projekt psychologii naukowej. [W:] Józef Kremer (1806-1875). Red. Jacek Maj. Kraków: Universitas, ss. 121-133. ISBN 97883-242-0748-0.

Duchiński, Franciszek 1859: Zasady dziejów Polski, innych krajów stowiańskich i Moskwy. Czesśc 2. Paryż: w drukarni Renou i Maulde.

Dziekoński, Józef 1841: Związek sił żywotnych z organizmem. Biblioteka Warszawska 3, ss. 635-668.

Encyklopedia Powszechna: zbiór wiadomości najpotrzebniejszych dla wszystkich stanów (1835-1839). Red. A. Chlebowicz, L. Rogalski, A. Odyniec. T. 1-4. Wilno-Warszawa: A. Glücksberg, T. Glücksberg.

Gall, Franz; Spurzheim, Johann 1809: Recherches sur le système nerveux en général et sur celui du cerveau en particulier. Paris: F. Schoell \& H. Nicolle

Gronkiewicz, Stanisław 1987: Pierwsza polska <Antropologia> i jej autor Józef Jasiński. Præeglad Antropologiczny 53 (1-2), ss. 29-34.

Jarocki, Feliks Paweł 1821: Zoologia cayli Zwieræ̨topismo ogólne: podtug najnowszego systematu utożone. T. 1. Warszawa: Lątkiewicz

Jasiewicz, Zbigniew 2010a: Początki etnologii/antropologii kulturowej w Polsce. Poszukiwanie nazw dla zainteresowań badawczych i rodzącej się dyscypliny. [W:] Antropolog wobec wspótczesności. Red. M. Radkowska-Walkowicz, A. Malewska-Szałygin. Warszawa: IEiAK UW, ss. 36-51. ISBN 
Jasiewicz, Zbigniew 2010b: Studia nad literatura ludowa, etnografia, etnologia, antropologia. Kierunki zainteresowań kształtującej się w połowie XIX wieku polskiej etnologii/antropologii kulturowej. Lud 94, ss. 191-220.

Jasiński, Józef 1818: Anthropologia o wtasnościach człowieka fizycznych $i$ moralnych. Wilno: nakładem J. Zawadzkiego.

Jundziłł, Stanisław 1805: O potrzebie układowey Nomenklatury w przedmiotach Historyi naturalnej. Driennik. Wileński 2 (6), ss. 163-173.

Jundziłł, Stanisław 1807: Zoologia krótko zebrana. Wilno: drukiem J. Zawadzkiego.

Kilka słów o etnologii 1850: Pamiętnik Literacki. Pismo tygodniowe 29, ss. 675-690.

Kluk, Krzysztof 1809 [1779]: Zwierzqt domowych i dzikich osobliwie krajowych, historii naturalnej poczqtki i gospodarstwo. Warszawa: w Drukarni Księży Pijarów.

Kołłątaj, Hugo 1842: Rozbiór krytyczny zasad bistorii o poczatkach rodu ludzkiego. T. 2. Kraków: Drukarnia Uniwersytecka.

Kossakowski, Jan 1804: Rzut oka na literaturę czeską i związek języków słowiańskich. Roczniki Towarzystwa Warszawskiego Prayjaciół Nauk 3, ss. 11-45.

Kronika paryska 1857: Biblioteka Warszawska 2, ss. 155-159.

Kuberski, Franciszek 1817: Krótki rys historii naturalnej. Lublin: w drukarni J. K. Pruskiego.

Kucharski, Andrzej 1854: Etnografia Turków i ich pobratymców. Biblioteka Warszanska 3, ss. 548-561.

Kumelski, Norbert; Górski, Stanisław 1836: Zoologia cæyli historia naturalna zwierzat. T. 1. Wilno: T. Glücksberg.

Lelewel, Joachim 1815: Hisoryka tudzież o tatwem i poṡytecznem nauczaniu historii. Wilno: A. Żółkowski.

Lelewel, Joachim 1826: O bistorii, jej rozgatezieniach i naukach zwiazek z nia majacych. Warszawa: drukarnia J. Pukszty.

Libelt, Karol 1844: O posłannictwie dziejowem narodów. Przeglad Nankowy literaturze, wiedzy i umnictwu poświęcony 1 (1), ss. 1-12.

Majewski, Walenty 1827: Zbiór rozpraw podtug dziatów nauk i umiejętności, bistorya wedrówek, przesiedleń i prz̨enosin, ogólnq i szczególna, ludów i narodów odrębnych rass cayli plemienni z jednej do drugiej krawedzi kuli ziemskiej wyjaśniajacych. T. 1. Warszawa: Nakład Autora.

Marczyński, Wawrzyniec 1817: Dzieie od Stworzenia Świata aż do Roku 1816, czyli Rys Historyi, Powszechney wszystkich narodów chronologicznnie ulożony. Poczajów: [s.n.]

Naruszewicz, Adam 1824: Historia narodu polskiego. T. 1. Warszawa: Drukiem N. Glücksberga 
Nowy Buffon dla mtodzieży czyli Treść Poczqtkowa Historyi naturalney. (1806). Z franc. tłum. R. W. K., t. 1. Warszawa: w Drukarniach połączonych Gazety Warszawskiej i Sukcesorów Tomasza Le Brun

Pietruski, Stanisław 1853: Historia naturalna zwierzat ssacych dzilkich galicyjskich. Lwów: Zakład Narodowy im. Ossolińskich

Piśmiennictwo dzisiejsze 1850: Pamiętnik Literacki. Pismo tygodniowe 2, ss. 25-31; 3, ss. 49-62.

Płonka-Syroka, Bożena 2007: Niemiecka medycyna romantyczna. Warszawa: DiG

Płonka-Syroka, Bożena 2015: Niemiecka medycyna romantyczna (1797-1848) w opiniach przedstawicieli polskiego środowiska naukowego do 1863 roku. Wiek XIX. Rocznik Towarzystwa Literackiego im. Adama Mickiewicza. VIII (L), ss. 103-122.

Podział nauki przyrodzenia 1819: Pamiętnik Naukowy Stużacy za Ciag Dalszy Ćmiczeń Nankowych. Oddziat matematyczno-Fizyczny 1 (1), ss. 21-22.

Pol, Wincenty 1850: Rzut oka na umiejetność geografii ze stanowiska uniwersyteckiego wykładu. Kraków: Drukarnia Uniwersytetu

Przybylski, Wacław 1852: Wstęp. [W:] d'Omalius d'Halloy, J. O rasach ludqkich çyli zasady etnografii. Wstęp i tłum. W. P. Wilno: J. Zawadzki.

Przybylski, Wacław 1857: Przekłady $i$ studia. Wilno: J. Zawadzki.

Rymarkiewicz, Jan 1849: Krótki rozkład nauki o narodowości Ethnologia zwanej. Poznań: nakładem i drukiem W. Stefańskiego.

Rzewuski, Stanisław 1830: Myśli o zastosowaniu fisyologii do bistoryi, mianowicie polskiej. Warszawa: s.n.

S. P. 1849: Berghaus: Physikalisches Atlas. Gotta. Biblioteka Warszawska 1, ss. 161-164 .

Sokolewicz, Zofia 2015: Etnografia/etnologia/antropologia a nauki historyczne wobec społeczeństwa pierwotnego. Rocznik. Antropologii historii (8), ss. 17-26.

Sołtyk, Michał 1798: Encyklopedya Wiadomości Elementarnych Cayli Pierwsze Rysy i Wyobrażenia Nauk i Kunsztów. Kraków: Drukarnia Szkoły Głównej Koronnej.

Surowiecki, Wawrzyniec 1822: O charakterze pisma runicznego. Warszawa: Drukarnia XX Pijarów.

Surowiecki, Wawrzyniec 1824: Śledzenie poczatku Narodów Stowiańskich. Warszawa: Drukarnia XX Pijarów.

Śniadecki, Jędrzej 1811: Teorya Jestestw Organicznych. T. 2. Wilno: nakładem J. Zawadzkiego. 
Tucker, Aviezer 2009: Historiografia - ewolucyjna nauka o transmisji informacji. Historyka XXXIX, ss. 67-87.

W. P. zob. Przybylski Wacław.

Waga, Antoni 1819: Rozprawa o naukach prayrodzonych, a w szczególności o historii naturalnej. Warszawa: w Drukarni XX. Pijarów.

Waga, Antoni 1859: Historia naturalna: dzieto wskazujace pomoc do nauczania sie tej umiejętności, uważanych w głównych stanowiskach jej warostu. T. 1. Warszawa: w drukarni K. Kowalewskiego.

Wiszniewski, Michał 1988 [1837]: Charaktery rozumów ludzkich. Warszawa: PWN.

Wyrwicz, Karol 1770: Geografia Powszechna Czasów Teraźnieyszych Albo Opisanie krótkie Kraiów całego Świata. Warszawa: Drukarnia Jezuitów.

Wyrwicz, Karol 1787: Historya powszechna skrócona. T. 1. Warszawa: Drukarnia Nadworna J.K.Mci i Prze. Komisji Eduk. Narodo. 